\title{
Automated SEM/EDS Analysis for Assessment of Trace Cross-Contamination in 316L Stainless Steel Powders
}

\begin{abstract}
MARÍA J. BALART, XINJIANG HAO, and CLAIRE L. DAVIS
Following observations of microcracking in two, out of three, Additive manufactured (AM) $316 \mathrm{~L}$ steel samples, an investigation was undertaken to ascertain the root cause. Welding diagrams, taking into account composition and process parameters, could not generally account for the experimental observations of non-cracked versus cracked AM 316L samples. EBSD phase maps in all three AM samples exhibited a fully austenitic microstructure not only in the bulk sample but also near-surface. Analysis of microcracked regions in the AM samples showed the presence of local enrichment of $\mathrm{Ni}, \mathrm{Cu}$ and P. Automated SEM/EDS analysis on feedstock powder samples prepared for cross-section examination revealed a fine, foreign particulate contaminant, expected to arise from $\mathrm{NiCrCuP}$ alloy cross-contamination during atomization, to be completely embedded in a 316L powder particle. This type of contamination would not have been revealed on examination of powder mounted onto a SEM stub, a common approach to assess powder quality. Based on this analysis, it is recommended to consider including automated SEM/EDS analysis on powder cross-sections in any standardization protocol for quality control of powders, to increase the chances of detection and identification of fine cross-contaminants. It is also recommended that atomization of $\mathrm{NiCrCuP}$ alloy should no longer precede atomization of $316 \mathrm{~L}$ alloy.
\end{abstract}

https://doi.org/10.1007/s11661-021-06474-4

(c) The Author(s) 2021

$316 \mathrm{~L}$ stainless steel is one of the most common grades of austenitic stainless steel and is a versatile material widely being used across many industrial sectors such as offshore, marine, aerospace, nuclear, chemical and bioengineering due to their good combination of mechanical properties and corrosion resistance. $^{[1]} 316 \mathrm{~L}$ can be reliably additive manufactured (AM) ${ }^{[2,3]}$ Considerable increase in the complexity of alloys, products and processing routes has resulted from growth in the powder metallurgy sector ${ }^{[4-10]}$ in particular the metallic powder supply chain. ${ }^{[11]}$ This complexity is seen as a source of risks, challenges and opportunities to the broader supply chain for metal

MARÍA J. BALART is with the WMG - Advanced Manufacturing and Materials Centre (AMMC), University of Warwick, Coventry CV4 7AL, U.K. and with the WMG - Energy Innovation Centre (EIC), University of Warwick, Coventry CV4 7AL, U.K. Coantact e-mail: Maria.Balart-Murria@warwick.ac.uk. XINJIANG HAO is with the WMG - Advanced Manufacturing and Materials Centre (AMMC), University of Warwick and also with the Liberty Powder Metals, Materials Processing Institute, Eston Road, Middlesbrough TS6 6US, U.K. CLAIRE L. DAVIS is with the WMG - Advanced Manufacturing and Materials Centre (AMMC), University of Warwick.

Manuscript submitted June 25, 2021; accepted September 27, 2021.

Article published online December 1, 2021 powders, powder processing and manufacturing technologies and increased competition. ${ }^{[1]}$ A particular challenge is to prevent powder cross-contamination (CC) as this could adversely affect product properties. ${ }^{[12-17]}$

Another issue is that solidification cracking can occur during additive manufacturing, as reported by $\mathrm{Yu}$ et al. ${ }^{[18]}$ in a recent study on cracking susceptibility of AISI 316L and AISI 304 stainless steels parts produced by laser metal deposition. In that study, diagrams for weld solidification cracking susceptibility of austenitic stainless steels were used for the prediction of cracking susceptibility. It is well-known that $316 \mathrm{~L}$ stainless steel weld metals are susceptible to solidification cracking due to $\mathrm{S}$ and $\mathrm{P}$ trace impurity segregation along grain boundaries during the last stages of solidification. ${ }^{[19]}$ Empirically determined relationships between $\mathrm{S}+\mathrm{P}$ trace impurity contents, the ratio of $\mathrm{Cr}$ equivalent to $\mathrm{Ni}$ equivalent and cracking susceptibility have been determined in austenitic stainless steels weld metals, and critical transition boundaries proposed for non-cracking/cracking susceptibility as exemplified in Figure 4 of Reference 18. These findings are summarized in Table I. Furthermore, Si was also found to promote cracking. On the other hand, solidification cracking was not observed at a low $\mathrm{S}+\mathrm{P}+\mathrm{Si}$ level in conjunction with a 


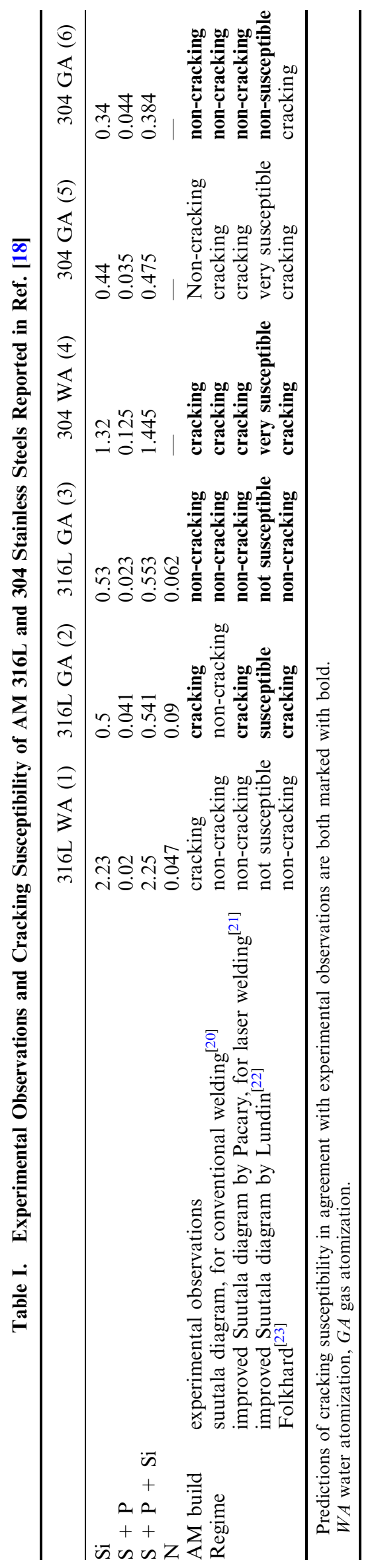

low $\mathrm{N}$ content for the $316 \mathrm{~L}$ steel and at a low $\mathrm{S}+\mathrm{P}+\mathrm{Si}$ level for the 304 steel.

A further issue affecting AM product performance is that $\mathrm{CC}$ of powder precursors can occur during powder production, handling and additive manufacturing. ${ }^{[12,13]}$ A general survey was made of contaminants in powder reported in the literature. These are summarized in Table II. Detailed information, where it is reported in the original publication, is organised in columns that include powder type, chemical analysis of elements present entirely or partly in the contaminant, chemical analysis method, contaminant type and form in the powder - discrete particle or embedded in powder where appropriate-, its size, technique used to detect and analyze the contaminant, its origin, other possible sources of contamination as described in the original paper, mechanical property investigated and references.

The most common method for powder assessment, and identification of contamination is to use powders mounted onto a SEM stub ${ }^{[13]}$ using for example, electrically conductive carbon tape ${ }^{[26,27,30]}$ or conductive glue. ${ }^{[25]}$ Contaminants are detected using backscattered electron imaging (BSEI) in conjunction with EDS analysis with automated morphological measurement and EDS data acquisition possible. The morphological and chemical dataset is then classified using a preset or modified classification scheme. The assessment of powder cross-sections prepared for micro-PIXE (proton induced X-ray emission) analysis, ${ }^{[24]}$ automated inclusion analysis ${ }^{[30]}$ and grain boundary engineering characterisation, ${ }^{[31,32]}$ is less commonly used for the characterisation of CC.

It is clear from the examples given in Table II for powder mounted onto a SEM stub that the contaminant particulates were coarse enough, with good atomic contrast to be identified in quasi-automated SEM/EDS analysis. There are also examples of where powder cross-sections were analyzed by micro-PIXE, automated inclusion analysis and STEM. The comparative advantage of the automated SEM/EDS analysis is that it is a high throughput technique, as it can combine the latest generation of EDS detectors and algorithms for both speed and accuracy. PIXE is a relatively new technique and, therefore, the accessibility is currently limited. ${ }^{24]}$ Sample preparation for STEM analysis required an intermediate layer of $17-4 \mathrm{PH}$ powder particles in-between two layers of electroplated Ni. Observations on the CC examples on powder cross-sections are listed in Table II. The three WC -6 wt pct Co grades analysed by PIXE were granules consisting of aggregates of fine particles $1.7-1.8 \mu \mathrm{m}$ in size, in which Fe was found to be the main impurity in the three grades and was primarily associated to the Co binder phase. Fe impurity levels $<0.3$ wt pct in WC-Co alloys are considered normal as $\mathrm{Fe}$ arises from recycling of cemented carbide ( $\mathrm{Fe}$ is sometimes the tough binder phase). The greater Fe impurity levels in the two $\mathrm{WC}-6 \mathrm{wt}$ pct Co in Table II were attributed to be due to under-loaded milling which could have caused intensifying wear of the stainless steel milling ball as there is a ball-to-powder ratio in ball-milling. ${ }^{[24]}$ While, the $17-4 \mathrm{PH}$ samples analyzed by STEM had some Cr-Mn-Al-Si-containing 


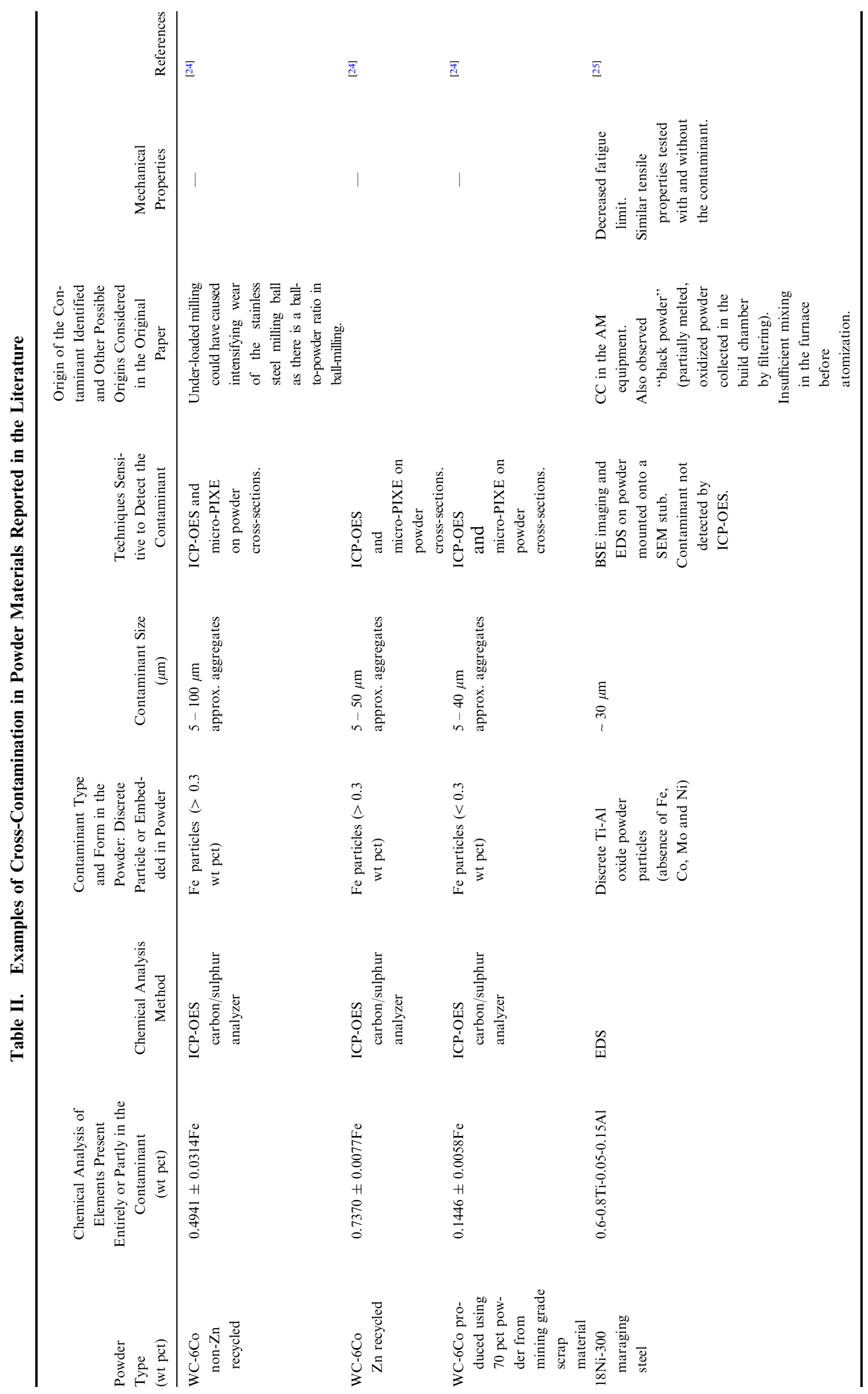




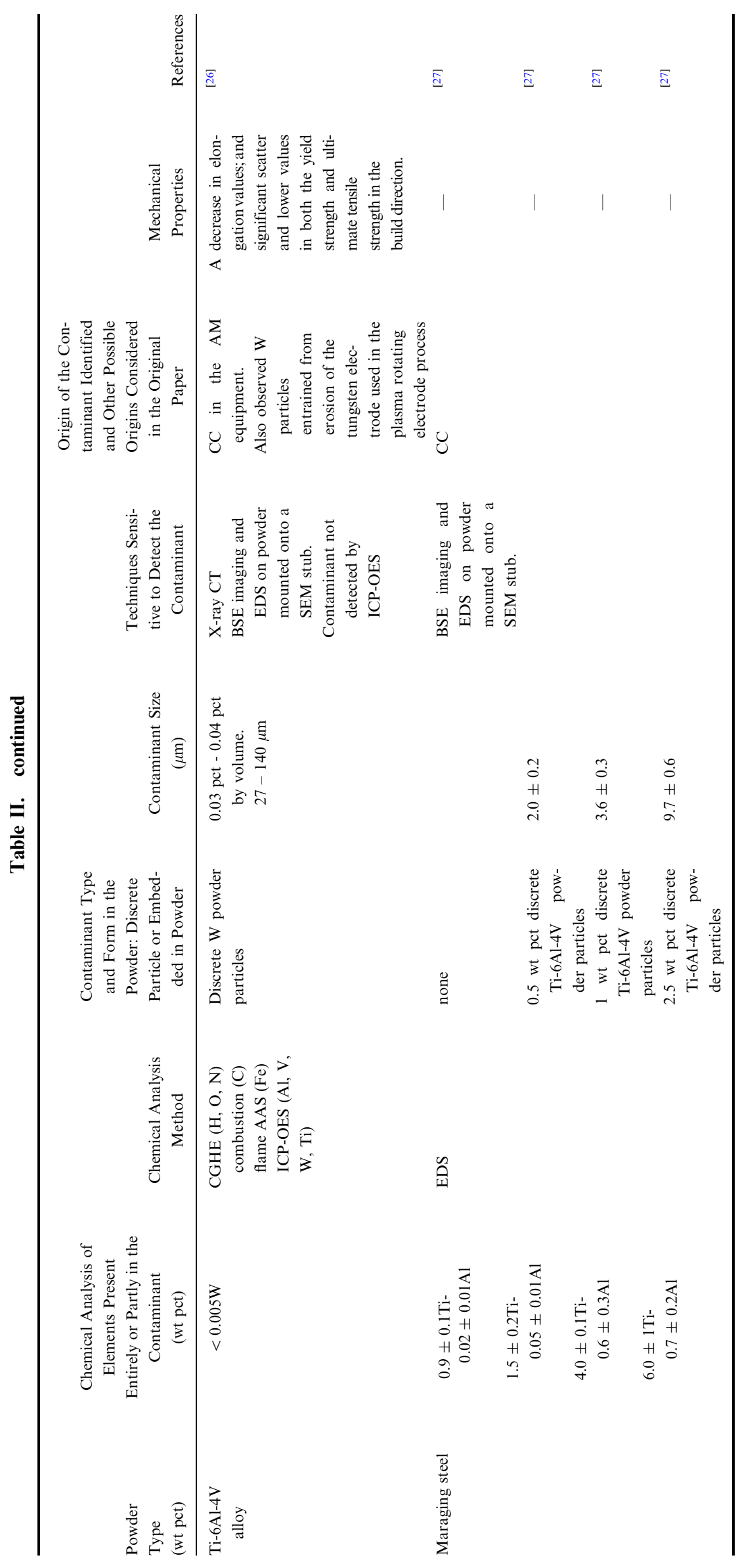




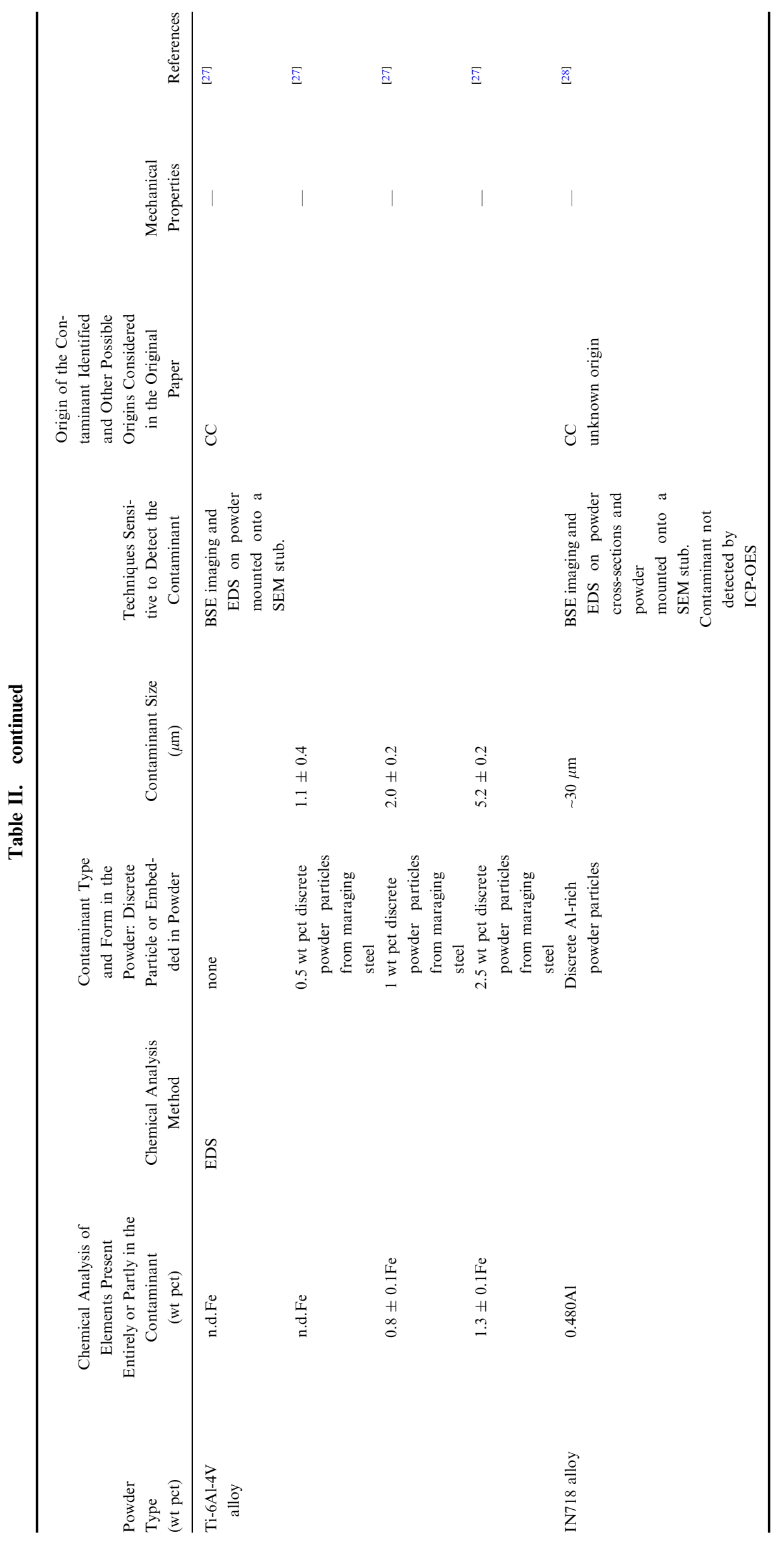

METALLURGICAL AND MATERIALS TRANSACTIONS A

VOLUME 53A, FEBRUARY 2022-349 


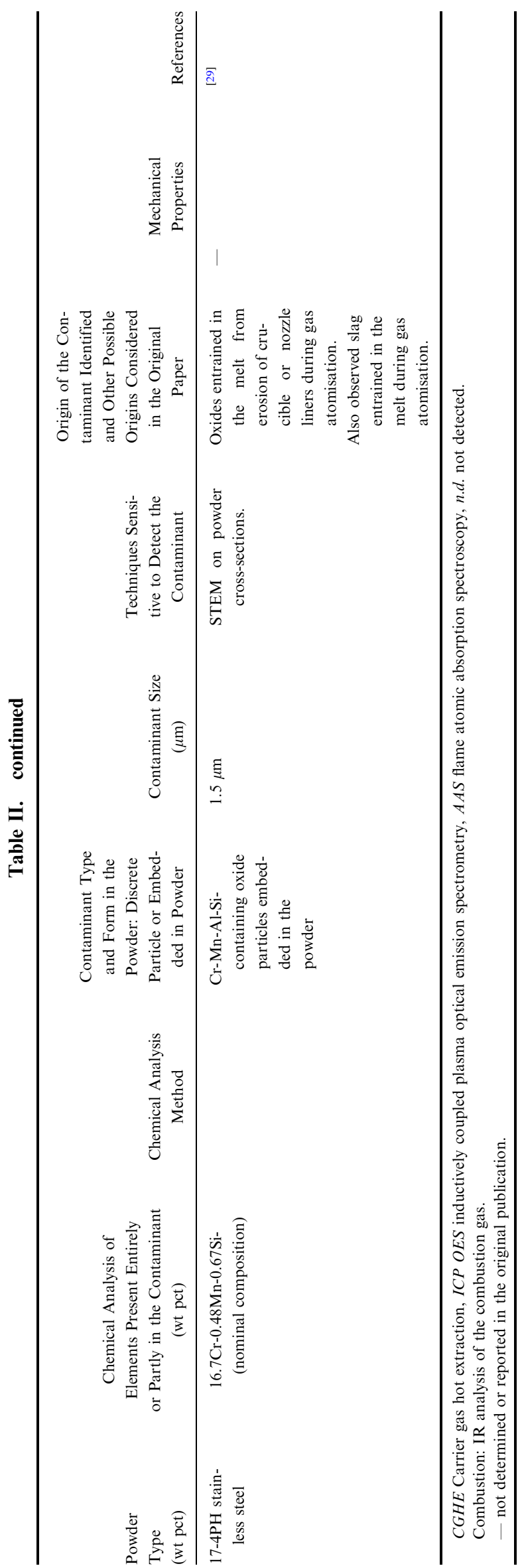

oxide particles with one example reported to be $1.5 \mu \mathrm{m}$ in size, completely embedded and close to the center of the powder particle of $\sim 10 \mu \mathrm{m}$ in cross-section size (see Figure 8 of Reference 29).

Here, we report observations of microcracks found during SEM examination of two AM 316L samples, which were built using two different compositional powders from the same commercial supplier. Conversely, no microcracks were found in another AM $316 \mathrm{~L}$ sample which was built using another powder from a different commercial supplier and with the same AM machine parameters. Following failure of the two 316L steels during AM building, an investigation was undertaken to ascertain the root cause. To this end, the cracking susceptibility has been assessed using the methodology described by $\mathrm{Yu}$ et $a l .{ }^{[18]}$ based on the original works by Suutala and Moisio, ${ }^{[20]}$ Pacary et al. ${ }^{[21]}$ Lundin et al. ${ }^{[22]}$ and Folkhard ${ }^{[23]}$ together with the residual $\mathrm{S}+\mathrm{P}, \mathrm{Si}$ and $\mathrm{N}$ levels, as highlighted in their work. ${ }^{[18]}$ Automated SEM/EDS analysis has been utilized for assessment of trace levels of CC in 316L powder on cross-sections.

Three different types of $316 \mathrm{~L}$ stainless steel powders $(<150 \mu \mathrm{m})$ produced by air-melted gas atomization (AMGA) were provided by Liberty Powder Metals from two suppliers (A and B). The $316 \mathrm{~L}$ powder from supplier A was sieved to 15 to $45 \mu \mathrm{m}$ and the other two $316 \mathrm{~L}$ powder samples from supplier B were sieved to 20 to $64 \mu \mathrm{m}$. All three powders were AM using SLM with a Renishaw AM 250 with the same standard parameters from the machine manufacturer Renishaw. $10 \mathrm{~mm} \times 10 \mathrm{~mm} \times 55 \mathrm{~mm}$ AM samples were built in the longitudinal direction.

The chemical composition of the 316L steel powders and the corresponding AM samples investigated as well as the minimum and maximum values as per steel specification ASTM A240 ${ }^{[33]}$ are given in Table III. The $\mathrm{C}, \mathrm{S}, \mathrm{N}$ and $\mathrm{O}$ contents of the samples were analyzed by LECO $^{\mathrm{TM}}$. The other elements were analyzed by inductively coupled plasma optical emission spectrometry (ICP-OES).

$1 \mathrm{~g}$ of each powder composition was cold mounted in epoxy resin, ground and polished to a $0.05 \mu \mathrm{m}$ non-crystallizing $\mathrm{SiO}_{2}$ polishing suspension finish. Cross-sections parallel to the build direction were mounted in conductive Bakelite and were also ground and polished to a $0.05 \mu \mathrm{m}$ non-crystallizing $\mathrm{SiO}_{2}$ polishing suspension finish.

First, secondary electron imaging and EDS were carried out on AM samples using a Zeiss Sigma FEG-SEM operating at $10 \mathrm{kV}$. Elemental analyses and EDAX mappings were processed using the AztecFeature OI software that integrates EDS analysis software with an XMax 50 SDD (Silicon Drift Detector).

Second, automated SEM in BSEI mode in conjunction with EDS analysis were carried out on polished powders using a Versa 3D dual beam SEM operating at $10 \mathrm{kV}$. Elemental analyses were processed using the AztecFeature OI software feature that integrates EDS analysis software with an XMax 80 SDD detector. Powder samples required cold mounting and Au sputtering in an Agar auto sputter coater, using a setting of 
Table III. Chemical Composition (Wt Pct) of the Investigated 316L Steels

\begin{tabular}{|c|c|c|c|c|c|c|c|c|c|c|c|c|}
\hline ASTM & A240 $0^{[33]}$ & $\mathrm{B}$ & $\mathrm{Co}$ & $\mathrm{Cr}$ & $\mathrm{Cu}$ & $\mathrm{Mn}$ & Mo & $\mathrm{Ni}$ & $\mathrm{P}$ & $\mathrm{Si}$ & $\mathrm{V}$ & W \\
\hline & & & & $16.0-18.0$ & - & $\begin{array}{l}2.00 \\
\max .\end{array}$ & $\begin{array}{l}2.00- \\
3.00\end{array}$ & $\begin{array}{l}10.0- \\
14.0\end{array}$ & $\begin{array}{l}0.045 \\
\max .\end{array}$ & $\begin{array}{l}0.75 \\
\max \end{array}$ & & \\
\hline $\begin{array}{l}\text { Supplier A } \\
\text { Powder A1 } \\
\text { Supplier B }\end{array}$ & $15-45 \mu \mathrm{m}$ & $<0.02$ & 0.04 & 16.67 & 0.07 & 0.53 & 2.32 & 12.49 & 0.017 & 0.6 & 0.04 & $<0.02$ \\
\hline Powder B1 & $20-64 \mu \mathrm{m}$ & $<0.02$ & 0.43 & 16.64 & 0.48 & 1.22 & 2.06 & 10.66 & 0.037 & 0.45 & 0.07 & 0.11 \\
\hline B2 & $20-64 \mu \mathrm{m}$ & $<0.02$ & 0.02 & 16.72 & 0.06 & 0.55 & 2.46 & 12.51 & 0.013 & 0.43 & 0.02 & $<0.02$ \\
\hline Uncracked & L sample A1 & $<0.02$ & 0.15 & 16.55 & 0.11 & 0.62 & 2.43 & 12.18 & 0.02 & 0.73 & 0.025 & 0.02 \\
\hline Cracked AN & sample B1 & $<0.02$ & 0.43 & 15.73 & 0.45 & 1.16 & 2.08 & 10.58 & 0.045 & 0.46 & 0.07 & 0.12 \\
\hline Cracked AN & sample B2 & $<0.02$ & 0.02 & 16.57 & 0.06 & 0.88 & 2.56 & 11.49 & 0.015 & 0.34 & 0.02 & $<0.02$ \\
\hline \multirow[t]{3}{*}{ ASTM } & $\mathrm{A} 240^{[33]}$ & $\mathrm{Sn}$ & $\mathrm{Ta}$ & $\mathrm{Al}$ & $\mathrm{Ti}$ & \multicolumn{2}{|c|}{$\mathrm{Nb}$} & $\mathrm{C}$ & $\mathrm{S}$ & $\mathrm{N}$ & $\mathrm{O}$ & $\mathrm{Fe}$ \\
\hline & & & & & & & & 0.030 & 0.03 & 0.10 & & bal. \\
\hline & & & & & & & & $\max$ & $\max$ & $\max$ & & \\
\hline \multicolumn{13}{|l|}{ Supplier $A$} \\
\hline \multicolumn{12}{|l|}{ Supplier B } & bal. \\
\hline Powder B1 & $20-64 \mu \mathrm{m}$ & $<0.02$ & $<0.02$ & $<0.05$ & $<0.02$ & & & 0.0085 & 0.0173 & 0.0271 & 0.0642 & bal. \\
\hline B2 & $20-64 \mu \mathrm{m}$ & $<0.02$ & $<0.02$ & $<0.05$ & $<0.02$ & & & 0.0164 & 0.0046 & 0.0581 & 0.0467 & bal. \\
\hline Uncracked & L sample A1 & $<0.02$ & $<0.02$ & $<0.05$ & $<0.02$ & & & 0.0300 & 0.0056 & 0.0998 & 0.0567 & bal. \\
\hline Cracked AN & sample B1 & $<0.02$ & $<0.02$ & $<0.05$ & $<0.02$ & & & 0.0147 & 0.0142 & 0.0247 & 0.0636 & bal. \\
\hline Cracked AN & sample B2 & $<0.02$ & $<0.02$ & $<0.05$ & $<0.02$ & & & 0.0275 & 0.0041 & 0.0593 & 0.0459 & bal. \\
\hline
\end{tabular}

- There is no requirement, and analysis for the element need not be determined or reported.

$40 \mathrm{~mA}$, for $30 \mathrm{sec}$. AztecFeature OI software was used to identify foreign particles in the powder samples. EBSD maps were collected from AM samples at $20 \mathrm{kV}$ accelerating voltage and $0.5 \mu \mathrm{m}$ step size. Phase maps were also processed using Aztec OI software.

BSEI and EDAX mapping of elements identified $\mathrm{Ni}-\mathrm{Cu}-\mathrm{P}$-rich regions near the microcracks in the bulk of the two AM 316L samples from the second powder supplier. Two examples are shown in Figures 1 and 2. The significance of this observation will be discussed below. In contrast, the AM 316L sample from the first powder supplier did not crack, Figure 3. Experimental observations and cracking susceptibility predictions according to the aforementioned study by $\mathrm{Yu}$ et al. ${ }^{[18]}$ together with the residual $\mathrm{S}+\mathrm{P}, \mathrm{Si}$ and $\mathrm{N}$ levels are given in Table IV and are plotted in Figure 4. Yu et al.'s results ${ }^{[18]}$ are also represented for comparative purposes. EBSD phase maps in all three AM samples exhibited a fully austenitic microstructure not only in the bulk sample but also near-surface, as exemplified in Figures 1(b) and (c), 2(c) and (d) and 3(a) through (c).

Failure of the two $316 \mathrm{~L}$ steels during AM would not be initially expected given the fact that $316 \mathrm{~L}$ can consistently be $\mathrm{AM},{ }^{[2,3]}$ and that the values of $\mathrm{S}+\mathrm{P}+$ $\mathrm{Si}$ and $\mathrm{N}$ levels (in wt pct) for the cracked AM 316L sample B2 are lower than those for the uncracked AM 316L sample, but the $\mathrm{S}+\mathrm{P}$ level is higher, Table IV. The cracking susceptibility predictions, Table IV and Figure 4, from the abovementioned welding diagrams cannot generally account for the experimental observations of non-cracked versus cracked AM 316L samples.

The values of $\mathrm{S}+\mathrm{P}, \mathrm{S}+\mathrm{P}+\mathrm{Si}$ and $\mathrm{N}$ levels (in wt pct) for the uncracked AM 316L sample of the present investigation are $0.024 \mathrm{wt}$ pct, $0.624 \mathrm{wt}$ pct and $0.089 \mathrm{wt}$ pct, respectively compared with the values given in Reference 18: 0.023 wt pct, 0.553 wt pct and $0.062 \mathrm{wt}$ pct, for the uncracked AM 316L sample; and $0.041 \mathrm{wt}$ pct, 0.541 wt pet and 0.09 wt pct, for the cracked AM $316 \mathrm{~L}$ sample. This suggests the requirement of low $\mathrm{S}+\mathrm{P}$ impurity levels $(<0.024 \mathrm{wt}$ pct $)$ at the high $\mathrm{N}$ contents of $0.062 \mathrm{wt}$ pet and $0.089 \mathrm{wt}$ pet for uncracking.

An automated BSEI of the area of analysis for the initial $316 \mathrm{~L}$ powder B1 $(<150 \mu \mathrm{m})$ is shown in Figure. 5 (a). 6043 fields of $59 \times 85.8 \times 10^{-6} \mathrm{~mm}^{2}$ each and an area of resin of $16.2 \mathrm{~mm}^{2}$ were analysed corresponding to a scanned area of $14.4 \mathrm{~mm}^{2}$ and $>10,000$ particles. BS ISO 13322-1:2014 ${ }^{[38]}$ and NIST $^{[39]}$ recommended to measure around 10,000 particles for statistical robustness as determined by the relative standard deviation for 

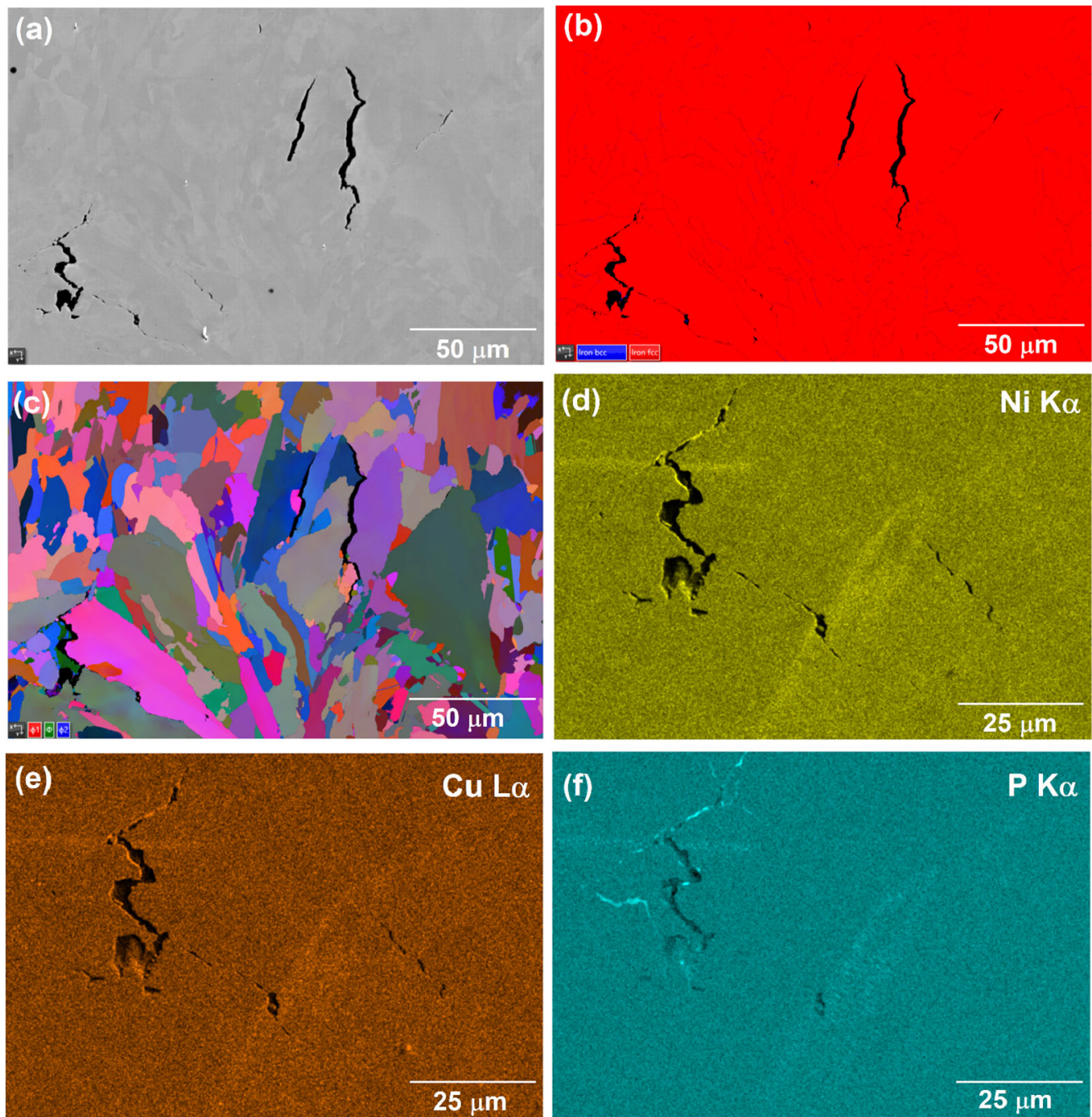

Fig. 1-Microcracks in the AM 316L sample from powder B1 (a) BSE micrograph, $(b)$ phase map, (c) EBSD micrograph, and mapping of elements $(d) \mathrm{Ni},(e) \mathrm{Cu}$ and $(f) \mathrm{P}$. Cross-sections taken along the build direction from top to bottom of the page.

morphological shape descriptors such as particle size and shape factors. It is expected that some particles could be contaminants.

From Figure 5(a), a fine, foreign particulate contaminant, completely embedded in a $316 \mathrm{~L}$ powder particle was sampled as shown in Figures 5(b) through (d). This is indicative of $\mathrm{CC}$ during atomization. Its EDS analysis is given in Table V. Following our analysis and communication with the supplier, it was confirmed that the observed foreign particulate originated from CC from previous production material - a low-melting $\mathrm{NiCrCuP}$ alloy powder-melting temperature $1173 \mathrm{~K}$ $\left(900{ }^{\circ} \mathrm{C}\right)$ approx. compared with $1673 \mathrm{~K}\left(1400{ }^{\circ} \mathrm{C}\right)$ for 316L steel-. The major differences between the $1.5 \mu \mathrm{m}$ sized inclusion shown in Figure 8 of Reference 29 and the inclusion shown in Figures 5(b) through (d) are that the melting point of the oxide contaminant particulate is higher that the surrounding steel matrix, as opposed to the low-melting $\mathrm{NiCrCuP}$ alloy contaminant of Figure 5, and while in the former case the contaminant is located close to the centre of the powder particle, in the latter case the contaminant is located near-surface. Both are fine, foreign particulate contaminants, though. The high stability and high melting temperatures of refractory oxide contaminants mean that these could have been engulfed by droplets of molten steel during solidification. By contrast, in the present investigation, the opposite trend has been observed. It is possible that 

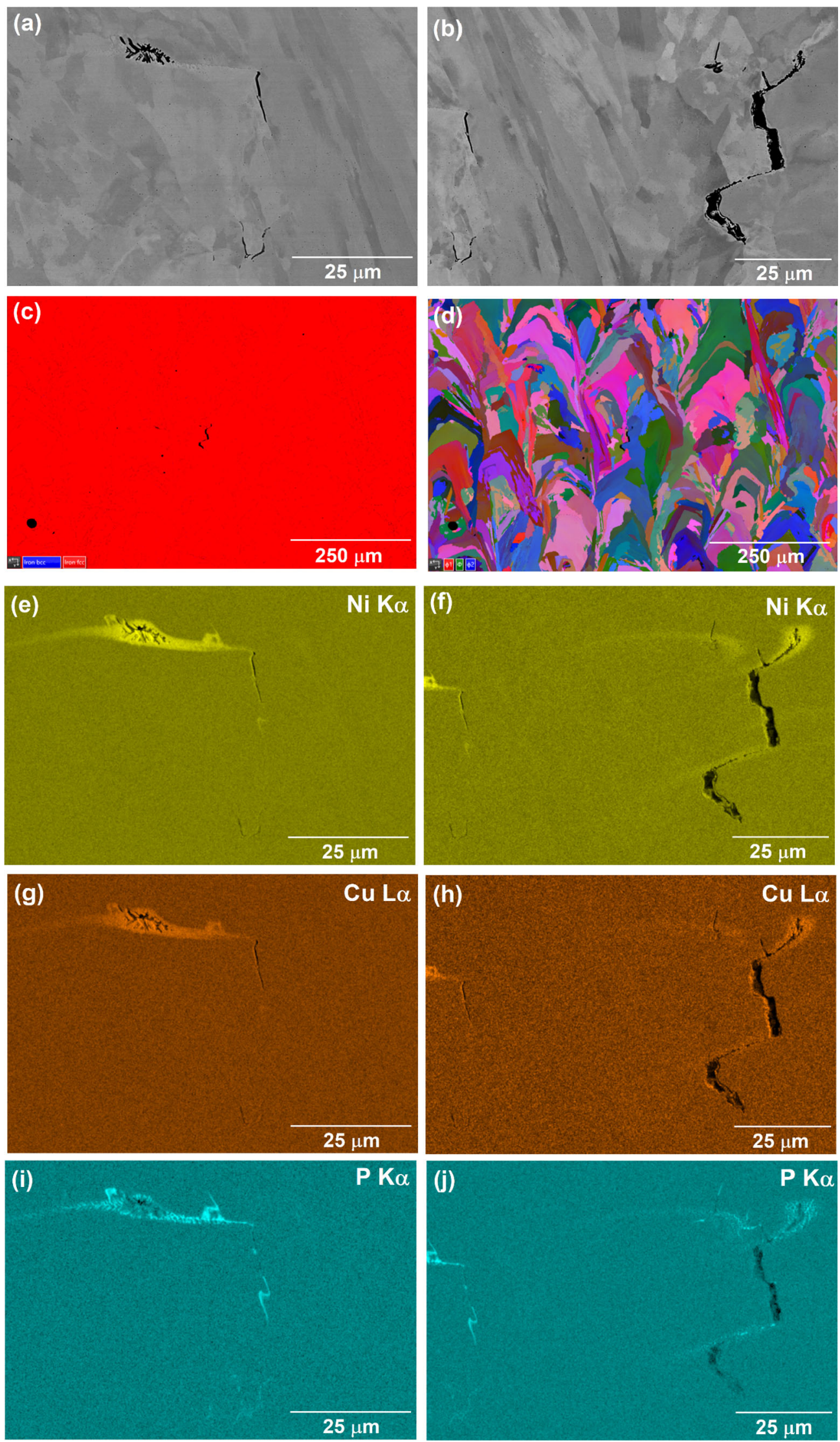

Fig. 2-Microcracks in the AM 316L sample from powder B2 (a) and (b) BSE micrographs, (c) phase map, (d) EBSD micrograph and mapping of elements $(e)$ and $(f) \mathrm{Ni},(g)$ and $(h) \mathrm{Cu}$ and $(i)$ and $(j) \mathrm{P}$. Cross-sections taken along the build direction from top to bottom of the page. 

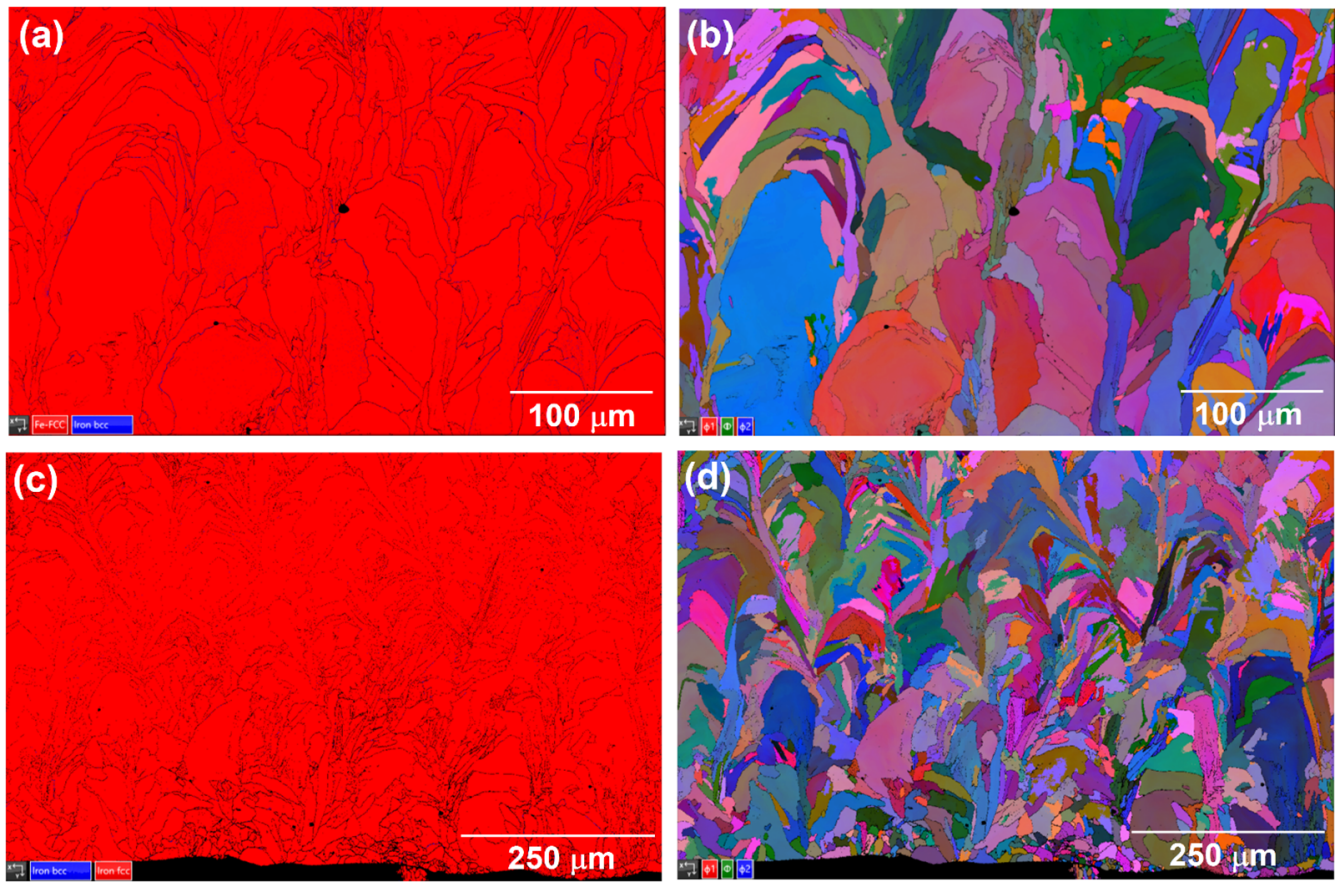

Fig. 3-AM 316L sample from powder A1 (a) and (b) bulk sample and (c) and (d) near-surface: (a) and (c) phase maps and (b) and (d) EBSD micrographs. Cross-sections taken along the build direction from top to bottom of the page.

rapid impingement and engulfment of droplets during atomization could have caused low-melting point contaminants to be embedded near-surface in the higher melting point steel matrix

It is interesting to note that the $\mathrm{CC}$ particle is fully embedded in the $316 \mathrm{~L}$ powder particle, and therefore would not be observable unless powder cross-sections are analyzed. It also suggests that the probability of detecting the contamination may be low (typically have low levels of CC coupled with a sectioning effect). It would appear that in this case there was significant CC as it resulted in a significant area of locally enriched composition, Figures 1 and 2, that caused microcracking. From microcracking observations in the present investigation, atomization of $\mathrm{NiCrCuP}$ alloy should no longer precede atomization of $316 \mathrm{~L}$ alloy as $\mathrm{CC}$ is causing cracking susceptibility.

Our communication with the supplier has helped to resolve the root cause of the $\mathrm{CC}$ issue during atomization on this occasion, as it has been possible to track the material that preceded atomization of the $316 \mathrm{~L}$ steels of the present investigation. The low-melting $\mathrm{NiCrCuP}$ alloy contaminant was found to be wholly embedded in the $316 \mathrm{~L}$ particle, indicating that $\mathrm{CC}$ occurred in the melting vessel / atomization nozzle. It is clear that by solely cleaning the collection chamber, the problem is not solved. An example from the literature in which CC occurred in the melting vessel, but due to oxides entrained in the melt from erosion of crucible or nozzle liners during gas atomisation of the $17-4 \mathrm{PH}$ steel, is given in Table II. Likewise, the oxide contaminant was found to be wholly embedded in the 17-4PH powder particle, as outlined above. Sun et al. ${ }^{[29]}$ highlighted that advanced atomization techniques prevent the melt being in contact with potential contamination sources. These are, however, more expensive techniques and infrequently used for replacement of standard atomization. On the grounds that it is challenging the detection of contaminants in the feedstock powder and when CC occurs in the AM machine, Brandão et al. ${ }^{[26]}$ recommended using one AM machine per feedstock powder for critical applications such as aerospace.

In the studies summarized in Table II, the results of the ICP analysis for $18 \mathrm{Ni}-300$ maraging steel, ${ }^{[25]}$ 
Table IV. Experimental Observations and Cracking Susceptibility of the Investigated 316L Steels

\begin{tabular}{|c|c|c|c|c|}
\hline & {$[18]$} & $\mathrm{A} 1,15-45 \mu \mathrm{m}$ & $\mathrm{B} 1,20-64 \mu \mathrm{m}$ & $\mathrm{B} 2,20-64 \mu \mathrm{m}$ \\
\hline & $\operatorname{DeLong}^{[34]}$ & & & \\
\hline $\mathrm{Cr}_{\mathrm{eq}}$ & $\mathrm{Cr}+\mathrm{Mo}+1.5 \mathrm{Si}+0.5 \mathrm{Nb}$ & 19.89 & 19.38 & 19.83 \\
\hline $\mathrm{Ni}_{\mathrm{eq}}$ & $\mathrm{Ni}+0.5 \mathrm{Mn}+30 \mathrm{C}+30 \mathrm{~N}$ & 16.14 & 12.34 & 15.02 \\
\hline $\mathrm{Cr}_{\mathrm{eq}} / \mathrm{Ni}_{\mathrm{eq}}$ & & 1.23 & 1.57 & 1.32 \\
\hline \multirow[t]{2}{*}{ Phase } & & A & FA & $\mathrm{AF}$ \\
\hline & Schaeffler $^{[35]}$ & & & \\
\hline $\mathrm{Cr}_{\mathrm{eq}}$ & $\mathrm{Cr}+\mathrm{Mo}+1.5 \mathrm{Si}+0.5 \mathrm{Nb}$ & 19.89 & 19.38 & 19.83 \\
\hline $\mathrm{Ni}_{\mathrm{eq}}$ & $\mathrm{Ni}+0.5 \mathrm{Mn}+30 \mathrm{C}$ & 13.48 & 11.53 & 13.28 \\
\hline $\mathrm{Cr}_{\mathrm{eq}} / \mathrm{Ni}_{\mathrm{eq}}$ & & 1.48 & 1.68 & 1.49 \\
\hline \multirow[t]{2}{*}{ Phase } & & FA & FA & FA \\
\hline & WRC-1992 (Siewert) ${ }^{[36]}$ & & & \\
\hline $\mathrm{Cr}_{\mathrm{eq}}$ & $\mathrm{Cr}+\mathrm{Mo}+0.7 \mathrm{Nb}$ & 18.99 & 18.70 & 19.18 \\
\hline $\mathrm{Ni}_{\mathrm{eq}}$ & $\mathrm{Ni}+35 \mathrm{C}+20 \mathrm{~N}+0.25 \mathrm{Cu}$ & 15.13 & 11.62 & 14.26 \\
\hline $\mathrm{Cr}_{\mathrm{eq}} / \mathrm{Ni}_{\mathrm{eq}}$ & & 1.26 & 1.61 & 1.34 \\
\hline \multirow[t]{2}{*}{ Phase } & & $\mathrm{AF}$ & FA & $\mathrm{AF}$ \\
\hline & HS (Hammar, Svennson) ${ }^{[37]}$ & & & \\
\hline $\mathrm{Cr}_{\mathrm{eq}}$ & $\mathrm{Cr}+1.37 \mathrm{Mo}+1.5 \mathrm{Si}+2 \mathrm{Nb}+3 \mathrm{Ti}$ & 20.75 & 20.14 & 20.74 \\
\hline $\mathrm{Ni}_{\text {eq }}$ & $\mathrm{Ni}+0.31 \mathrm{Mn}+22 \mathrm{C}+14.2 \mathrm{~N}+\mathrm{Cu}$ & 14.51 & 12.09 & 13.93 \\
\hline $\mathrm{Cr}_{\mathrm{eq}} / \mathrm{Ni}_{\mathrm{eq}}$ & & 1.43 & 1.67 & 1.49 \\
\hline Phase & & $\mathrm{AF}$ & FA & FA \\
\hline $\mathrm{Si}$ & & 0.6 & 0.45 & 0.43 \\
\hline $\mathrm{S}+\mathrm{P}$ & & 0.024 & 0.054 & 0.018 \\
\hline $\mathrm{S}+\mathrm{P}+\mathrm{Si}$ & & 0.624 & 0.504 & 0.448 \\
\hline $\mathrm{N}$ & & 0.089 & 0.027 & 0.058 \\
\hline AM build & Experimental observations & non-cracking & cracking & cracking \\
\hline Regime & Folkhard diagram ${ }^{[23]}$ & cracking & non-cracking & non-cracking \\
\hline \multirow[t]{3}{*}{$\begin{array}{l}\text { calculated from } \\
\qquad \mathrm{Cr}_{\mathrm{eq}} / \mathrm{Ni}_{\mathrm{eq}} \mathrm{HS}\end{array}$} & $\begin{array}{l}\text { Improved Suutala diagram } \\
\text { by Lundin et al. }{ }^{[22]}\end{array}$ & cracking & non-cracking & cracking \\
\hline & $\begin{array}{l}\text { Improved Suutala diagram } \\
\text { by Pacary et al. for laser welding }\end{array}$ & very susceptible & not susceptible & not susceptible \\
\hline & Suutala diagram, for conventional welding ${ }^{[20]}$ & non-cracking & cracking & non-cracking \\
\hline WRC ferrite No. & & 5 & 7 & 7 \\
\hline
\end{tabular}

Ti-6Al-4V alloy ${ }^{[26]}$ and IN718 alloy $^{[28]}$ powders indicated that the elements in the corresponding contaminants, namely Ti-Al oxides, W and Al-rich particles, were present at levels within the specification limits. Whereas ICP analysis in WC-6Co cemented carbides ${ }^{[24]}$ identified $\mathrm{Fe}$ impurities to be in excess of the normal limits $<0.3 \mathrm{wt}$ pct. From the chemical composition analysis in Table III, it may be seen that the contents of $\mathrm{Ni}$ and $\mathrm{P}$ are within the specification of ASTM A240.

Overall, these results have important implications for the development of standardization tools to increase the chances to detect, identify and track CC for quality control of powders introduced in the supply chain as very small amounts of contamination can be identified in powder cross-sections.
This investigation has been undertaken to ascertain the root cause of microcracking through comparing the results of a non-cracked versus two cracked AM 316L samples:

- Welding diagrams, taking into account composition and process parameters, could not generally account for the experimental observations of non-cracked versus cracked AM 316L samples. EBSD phase maps in all three AM samples exhibited a fully austenitic microstructure not only in the bulk sample but also near-surface. The uncracked AM 316L sample suggested very low levels of trace impurity elements $\mathrm{S}+\mathrm{P}$ impurity levels $(<0.024 \mathrm{wt} \mathrm{pct})$ are required at the high $\mathrm{N}$ content of $0.09 \mathrm{wt}$ pct. 


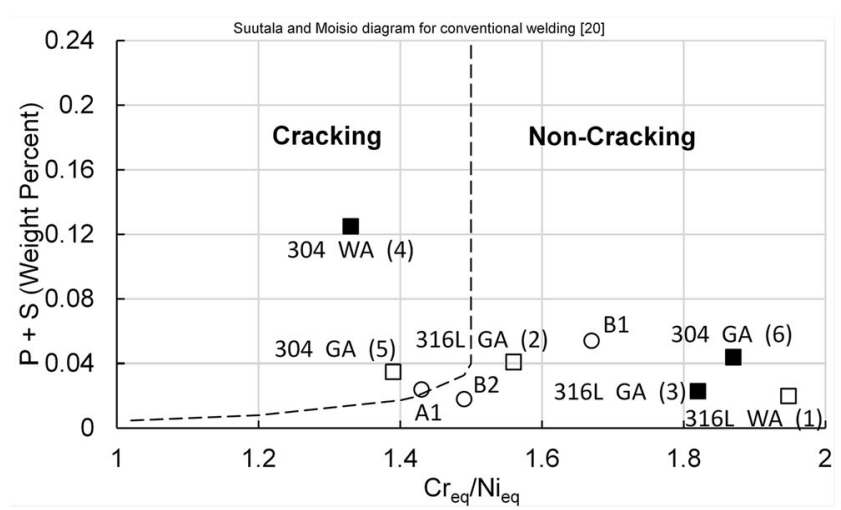

(a)

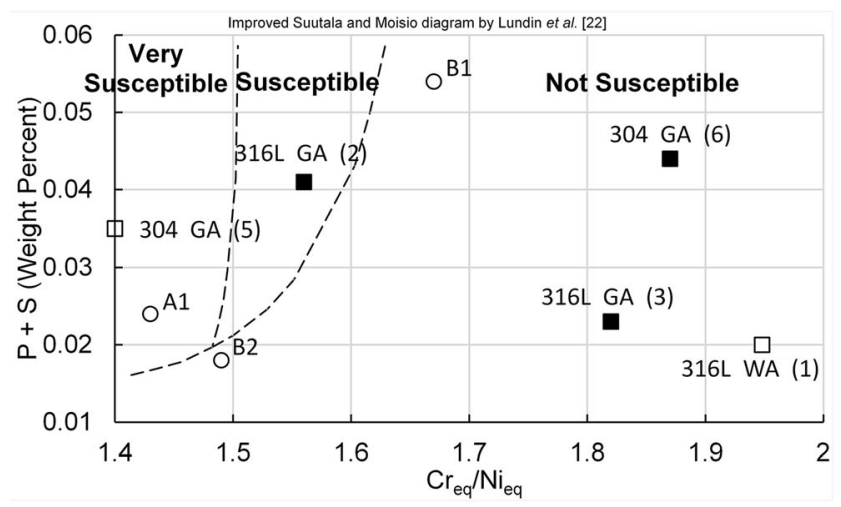

(c)

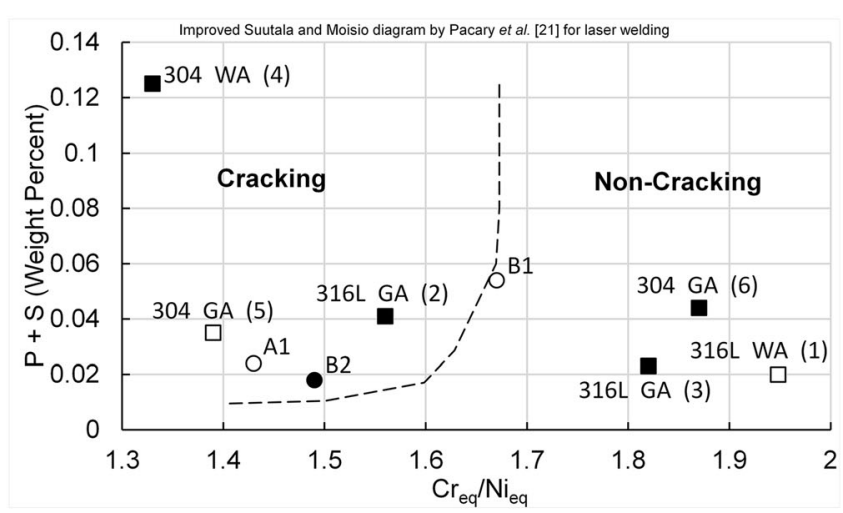

(b)

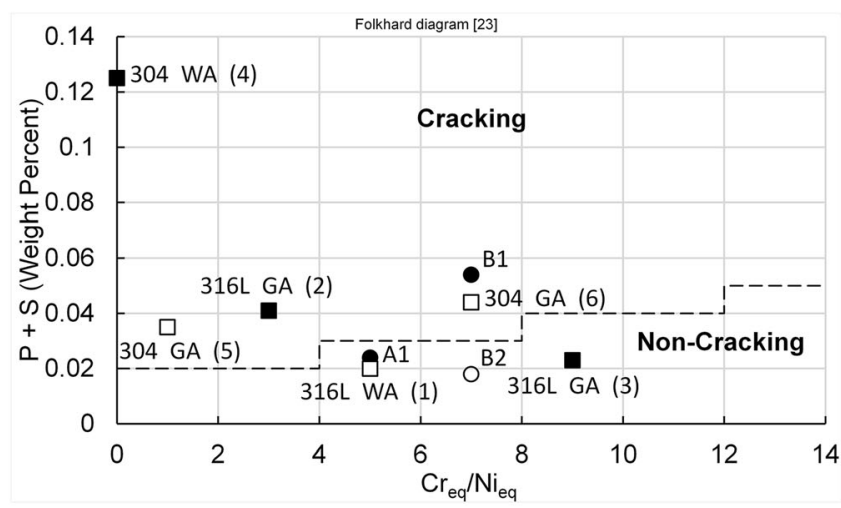

(d)

Fig. 4-Experimental observations and cracking susceptibility predictions from Tables I and IV in line with the work of Yu et al. ${ }^{[18]}(a)$ Suutala and Moisio diagram for conventional welding, ${ }^{[20]}(b)$ improved Suutala and Moisio diagram by Pacary et al. ${ }^{[21]}$ for laser welding, $(c)$ improved Suutala and Moisio diagram by Lundin et al. ${ }^{[22]}$ for laser welding and $(d)$ Folkhard diagram. ${ }^{[23]}$ Predictions of cracking susceptibility in agreement with experimental observations are marked with filled symbols, otherwise with unfilled symbols: squares symbols represent data adapted from Ref. [18] and circle symbols represent experimental observations of the present investigation. Reprinted with permission from Ref. [18] copyright 2013, Elsevier, https://doi.org/10.1016/j.matdes.2012.08.078.

Cracking was observed to be associated with a local enrichment in $\mathrm{Ni}, \mathrm{Cu}$ and $\mathrm{P}$ levels.

- Automated SEM/EDS analysis on powder cross-sections sampled a fine, foreign particulate contaminant from $\mathrm{NiCrCuP}$ alloy to be embedded in a $316 \mathrm{~L}$ powder particle, which would not have been revealed by analysis of powder particles mounted onto a SEM stub. The $\mathrm{NiCrCuP}$ originated as $\mathrm{CC}$ from the previous atomization batch, and it is suspected that it resulted in the local composition enrichment which was associated with cracking. Based on this analysis, it is recommended to consider including automated SEM/EDS analysis on powder cross-sections in any standardization protocol for quality control of powders, to increase the chances of detection and identification of fine cross-contaminants. It is also recommended that atomization of $\mathrm{NiCrCuP}$ alloy should no longer precede atomization of $316 \mathrm{~L}$ alloy.

The financial support of Liberty Powder Metals is gratefully acknowledged. This work was carried out as part of UK government's Advanced Manufacturing Supply Chain Initiative (AMSCI) - CASCADE project: Creating an advance manufacturing supply chain for net shape and AM parts which address the demands of end-users. 

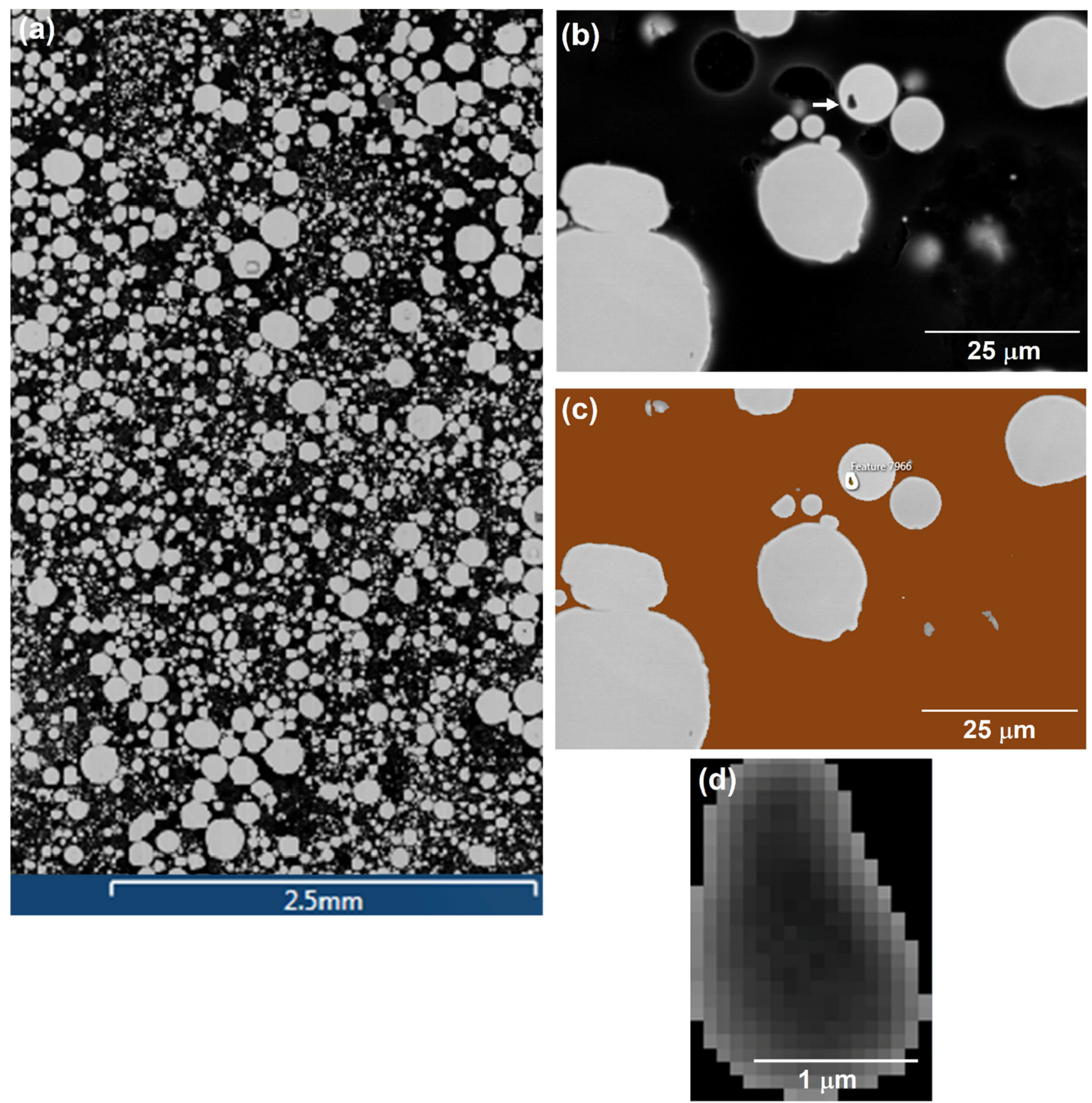

Fig. 5- (a) BSE macrograph for the 316L $<150 \mu \mathrm{m}$ powder B1 showing the area of analysis: $59 \times 85.8 \times 10^{-6} \mathrm{~mm}^{2}$ size of field, $6043 \mathrm{number}$ of fields, $16.2 \mathrm{~mm}^{2}$ area of resin and $14.4 \mathrm{~mm}^{2}$ area scanned. A fine, foreign particulate contaminant (arrowed) completely embedded in a $316 \mathrm{~L}$ powder particle $(b)$ BSEI, $(c)$ Imaging from a single grey threshold for detecting the contaminant and (d) BSEI of particulate contaminant in (b).

Table V. EDS Analysis (Wt Pet) From the NiCrCuP Alloy Particulate Contaminant in Fig. 5(d)

\begin{tabular}{lccccccc}
\hline $\mathrm{Ni}$ & $\mathrm{C}$ & $\mathrm{Cr}$ & $\mathrm{Cu}$ & $\mathrm{O}$ & $\mathrm{Si}$ & $\mathrm{P}$ & $\mathrm{Fe}$ \\
\hline $52.6 \pm 1.1$ & $11.2 \pm 1.5$ & $10.0 \pm 0.3$ & $7.2 \pm 0.5$ & $5.7 \pm 0.6$ & $5.7 \pm 0.2$ & $4.5 \pm 0.3$ & $3.0 \pm 0.2$ \\
\hline
\end{tabular}


The authors declare that they have no known competing financial interests or personal relationships that could have appeared to influence the work reported in this paper.

\section{OPEN ACCESS}

This article is licensed under a Creative Commons Attribution 4.0 International License, which permits use, sharing, adaptation, distribution and reproduction in any medium or format, as long as you give appropriate credit to the original author(s) and the source, provide a link to the Creative Commons licence, and indicate if changes were made. The images or other third party material in this article are included in the article's Creative Commons licence, unless indicated otherwise in a credit line to the material. If material is not included in the article's Creative Commons licence and your intended use is not permitted by statutory regulation or exceeds the permitted use, you will need to obtain permission directly from the copyright holder. To view a copy of this licence, visit http://creat ivecommons.org/licenses/by/4.0/.

\section{REFERENCES}

1. J.R. Davis, ed., ASM Speciality Handbook. Stainless Steels, 2nd ed., ASM International, Materials Park, OH, 1994.

2. M.J. Heiden, L.A. Deibler, J.M. Rodelas, J.R. Koepke, D.J. Tung, D.J. Saiz, and B.H. Jared: Addit. Manuf., 2019, vol. 25, pp. 84-103, https://doi.org/10.1016/j.addma.2018.10.019.

3. A.S. Wu, D.W. Brown, M. Kumar, G.F. Gallegos, and W.E. King: Metall. Mater. Trans. A, 2014, vol. 45A (13), pp. 6260-70, https://doi.org/10.1007/s11661-014-2549-x.

4. U. Engström and E. Schneider: in World Congress on Powder Metallurgy, Proceedings of World PM2018, Beijing, China, 16-20 September 2018, pp. 43-52.

5. V. Polard and B. Blitz: in World Congress on Powder Metallurgy, Proceedings of World PM2018, Beijing, China, 16-20 September 2018, pp. 1152-55.

6. R. Goto: in World Congress on Powder Metallurgy, Proceedings of World PM2018, Beijing, China, 16-20 September 2018, pp. 1979-82.

7. P. Gundermann: in Euro PM2018 Plenary presentation, Bilbao, Spain, 14-18 October 2018. https://www.europm2018.com/onsite-c ontent-access. Accessed 24 June 2021.

8. P. Bajaj, A. Hariharan, A. Kini, P. Kürnsteiner, D. Raabe, and EA. Jägle: Mater. Sci. Eng. A, 2020, vol. 772, art. no. 138633https://doi.org/10.1016/j.msea.2019.138633.

9. N. Li, S. Huang, G. Zhang, R. Qin, W. Liu, H. Xiong, G. Shi, and J. Blackburn: J. Mater. Sci. Technol., 2019, vol. 35 (2), pp. 242-69, https://doi.org/10.1016/j.jmst.2018.09.002.

10. H. Fayazfar, M. Salarian, A. Rogalsky, D. Sarker, P. Russo, V. Paserin, and E. Toyserkani: Mater. Des., 2018, vol. 144, pp. $98-128$, https://doi.org/10.1016/j.matdes.2018.02.018.

11. J. Dawes, R. Bowerman, and R. Trepleton: Johnson Matthey Technol. Rev., 2015, vol. 59 (3), pp. 243-56, https://doi.org/ $10.1595 / 205651315$ X688686.

12. E. Santecchia, P. Mengucci, A. Gatto, E. Bassoli, L. Denti, F. Bondioli, and G. Barucca: in Euro PM2018 Proceedings, Bilbao, Spain, 14-18 October 2018.

13. C. Blackwell, S. Hall, J. Dawes, and N. Brierley: in Euro PM2018 Proceedings, Bilbao, Spain, 14-18 October 2018.
14. B. Mooney and K.I. Kourousis, Metals, 2020, vol. 10, 1273. h ttps://doi.org/10.3390/met10091273.

15. M. Montazeri, R. Yavari, P. Rao, and P. Boulware: J. Manuf. Sci. Eng., 2018, vol. 140(11), 111001.https://doi.org/10.1115/1. 4040543.

16. E. Santecchia, P. Mengucci, A. Gatto, E. Bassoli, L. Denti, B. Gheorghiu, and G. Barucca: in Euro PM2019 Proceedings, Maastricht, The Netherlands, 13-16 October 2019.

17. M. Horn, L. Langer, M. Schafnitzel, S. Dietrich, G. Schlick, C. Seidel, and G. Reinhart: Procedia CIRP, 2020, Vol. 94, pp. 167-72. In 11th CIRP Conference on Photonic Technologies, LANE 2020; Virtual, Online, 7-10 September 2020.

18. J. Yu, M. Rombouts, and G. Maes: Mater. Des., 2013, vol. 45, pp. 228-35, https://doi.org/10.1016/j.matdes.2012.08.078.

19. J.A. Brooks and A.W. Thompson: Int. Mater. Rev., 1991, vol. 36 (1), pp. 16-24, https://doi.org/10.1179/imr.1991.36.1.16.

20. N. Suutala and T. Moisio: Solidification Technology in the Foundry and Casthouse, The Metals Society, London, 1980.

21. G. Pacary, M. Moline, and J.C. Lippold: EWI research brief no. B9008, 1990, Edison Welding Institute.

22. C.D. Lundin, C.H. Lee, and C.Y.P. Qiao: Group sponsored study-weldability and hot ductility behavior of nuclear grade austenitic stainless steels, Final report, Knoxville: Univ. of Tennessee, 1988.

23. E. Folkhard: Welding metallurgy of stainless steels, Springer Verlag, New York, 1988.

24. C.S. Freemantle, N. Sacks, M. Topic, and C.A. Pineda-Vargas: Int. J. Refract. Met. Hard Mater., 2014, vol. 44, pp. 94-102, https://doi.org/10.1016/j.ijrmhm.2014.01.019.

25. A. Gatto, E. Bassoli, and L. Denti: Addit. Manuf., 2018, vol. 24, pp. 13-19, https://doi.org/10.1016/j.addma.2018.09.004.

26. A.D. Brandão, R. Gerard, J. Gumpinger, S. Beretta, A. Makaya, L. Pambaguian, and T. Ghidini: Materials, 2017, vol. 10, 522, https://doi:https://doi.org/10.3390/ma10050522.

27. E. Santecchia, P. Mengucci, A. Gatto, E. Bassoli, S. Defanti, and G. Barucca: Materials, 2019, vol. 12, 2342; https://doi:https://doi. org $/ 10.3390 /$ ma 12152342.

28. M.J. Balart, X. Hao, S. Marks, G.D. West, and C.L. Davis: in Euro PM2019 Proceedings, Maastricht, The Netherlands, 13-16 October 2019.

29. Y. Sun, R.J. Hebert, and M. Aindow: Mater. Des., 2017, vol. 140, pp. 153-62, https://doi.org/10.1016/j.matdes.2017.11.063.

30. M.J. Balart, X. Hao, S. Marks, G.D. West, M. Walker, and C.L. Davis: MetallMater. Trans. A, 2020, vol. 51A (12), pp. 6439-60, https://doi.org/10.1007/s11661-020-06010-w.

31. S. Irukuvarghula, H. Hassanin, C. Cayron, MM. Attallah, D. Stewart, and M. Preuss: Acta Mater., 2017, vol. 133, pp. 269-81, https://doi.org/10.1016/j.actamat.2017.04.068.

32. M.J. Balart, H.G.C. Hamilton, X. Hao, M. Strangwood, and C.L. Davis: in Euro PM2018 Proceedings, Bilbao, Spain, 14-18 October 2018.

33. ASTM A240 / A240M-20a: Standard Specification for Chromium and Chromium-Nickel Stainless Steel Plate, Sheet, and Strip for Pressure Vessels and for General Applications, ASTM International, West Conshohocken, PA, 2020, www.astm.org.

34. W.T. DeLong: Weld. J. Res. Suppl., 1974, vol. 53, pp. s273-86.

35. A.L. Schaeffler: Met. Prog., 1949, vol. 56 (11), pp. 680-88.

36. D.J. Kotecki and T.A. Siewert: Weld J., 1992, vol. 71 (5), pp. $171-78$.

37. O. Hammer and U. Svensson: Solidification and Casting of Metals, The Metals Society, London, 1979, pp. 401-10.

38. BS ISO 13322-1:2014: Particle size analysis - Image analysis methods - Part 1: Static image analysis methods, 2014, www.iso. org.

39. A. Jillavenkatesa, S.J. Dapkunas, and L.-S. H. Lum: NIST Recommended Practical Guide Special Publication 960-1, Particle Size Characterization, January 2001.

Publisher's Note Springer Nature remains neutral with regard to jurisdictional claims in published maps and institutional affiliations. 